\title{
The Dilemmas of Digital Patrimonialization: The Digital Museum of African and Afro-Brazilian Memory
}

\author{
Livio Sansone
}

\begin{abstract}
Historically subaltern groups envisage new possibilities for the creation of community museums and exhibits. This seems to be particularly true of the Global South and, even more so, of Sub-Saharan Africa and the African diaspora to Southern America - two regions of the world where, when it concerns ethno-racial minorities and social movements, presential museums and "actual" archives have more often than not been poorly funded, ill-equipped, and underscored. This article teases out the process of creating such a digital museum that focuses on African and Afro-Brazilian heritage. It is a technological and political experiment that is being developed in a country experiencing a process of rediscovery and of the patrimonialization of a set of elements of popular culture, within which "Africa" as a trope has moved from being generally considered a historical onus to (Western-oriented)
\end{abstract}

History in Africa, Volume 40 (2013), pp. 257-273

Livio Sansone (Palermo, 1956) took his BA in sociology at the University of Rome and his MA and PhD at the University of Amsterdam (1992). Since 1992 Sansone has lived in Brazil, where he is Associate Professor of Anthropology at the Federal University of Bahia (UFBA). He heads the Factory of Ideas Program - an advanced international course in ethnic and racial studies - and coordinates the Digital Museum of African and Afro-Brazilian Heritage - www.museuafrodigital. ufba.br. He has published extensively on youth culture, ethnicity, inequalities, the international transit of ideas of race and antiracism, anthropology and colonialism, and globalization, with research based in the UK, the Netherlands, Suriname, Brazil, and, recently, Cape Verde, Senegal, and Guinea-Bissau. His best-known book in English is Blackness Without Ethnicity: Constructing Race in Brazil (New York: Palgrave, 2003). E-mail: sansone@ufba.br 
progress to become a bonus for a country that is discovering itself both multiculturally and as part of the powerful group of BRIC nations (Brazil/Russia/India/ China).

Résumé: Les groupes historiquement subalternes envisagent de nouvelles possibilités pour la création de musées et d'expositions communautaires. Ce phénomène semble particulièrement vrai dans le Grand Sud et plus encore en Afrique sub-saharienne et dans la diaspora africaine en Amérique du Sud, deux régions du monde où en ce qui concerne les minorités ethno-raciales et les mouvements sociaux, les musées des temps présents et les archives "d'actualités" sont le plus souvent mal soutenus financièrement, mal équipés, et mal représentés. Cet article montre par contraste le processus de création d'un musée digital se concentrant sur l'héritage africain et afro-brésilien. Il s'agit d'une expérimentation politique et technologique mise en ouvre dans un pays qui fait l'expérience d'une redécouverte et d'une mise en patrimoine d'éléments de la culture populaire, dans laquelle "l'Afrique" en tant que trope passe d'un état de poids historique sur un progrès orienté vers l'Occident vers un état de bonus pour un pays qui découvre son identité à la fois multiculturelle et en tant que membre du groupe puissant des nations BRIC (Brésil/Russie/Inde/Chine).

\section{Introduction ${ }^{1}$}

Over the last decade new communication technologies seem to have changed and broadened the horizon for museum exhibits as well as for heritage preservation more generally. A process that began in the more technologically developed nations has begun to make inroads into the Global South too, and the purpose of this short text is to introduce the Digital Museum of African and Afro-Brazilian Memory. The Digital Museum is a concrete intervention in the geopolitics of knowledge, an attempt to reverse the tradition of dividing the world into places where research is performed and popular culture is produced, and places where information and artefacts are kept, archived, and "secured," which tend to be where "Art" (with a capital A) is created and enshrined. The Digital Museum initiative is important to the knowledge and memory of African art and culture more generally, and in two ways: on the one hand, it concerns the rediscovery or perhaps the reinvention of Africa in its own diaspora; on the other hand, through a number of collaborative projects with African institutions (Mozambique Historical Archive, INEP-Guinea Bissau, IFAN-Dakar, University of Cape Verde) it relates to the establishment of a digital heritage for Africa and the rest of the Global South - emphasizing a critical and yet positive perspective on digitization itself and its preservation and circulation on the web. Our project has emerged from the currently contradictory cultural and multicultural politics of Brazil, where a new configuration is beginning to define itself by interaction between new communication technologies, state intervention within the sphere of the production of

1 I am indebted to John A. Mundell for the translation of this text. 
culture and identity, and new demands by historically subaltern groups that they be recognized.

\section{Background: Brazilian Cultural Politics}

In Brazil, at least since its independence, the State and elites have defined certain national characteristics and celebrated them by recourse to use of the term "the people." Since the 1930s the categories of "people" and "popular" have been settled through the production of a list of artefacts with the prospect of patrimonialization, by the National Foundation of the Arts (Funarte), the National Historic and Artistic Heritage Institute (IPHAN), and museums. ${ }^{2}$ Although the people were in fact kept at a distance from power, in a complex process part of popular culture became an essential component of the ideals of the nation. Within that process, "the African" assumed a symbolically central position, followed by "the Negro" and "the Indian." As Lilia Schwarcz showed, ${ }^{3}$ after 1830 the national debates of the Historical and Geographical Institute rewarded and celebrated the contribution of those "Others" to "Brazilian-ness." It was an incorporation of excess, more cultural than social and economic, in a process that created expectations between the subordinated and the racialized. ${ }^{4}$

The symbolic process of inclusion as representative of the nation has increased greatly, albeit in a context where, for decades, the State has been less obviously present and there has been more involvement by other agents, both physically present and virtual. Incorporation of the popular into the national began during Vargas's nationalist-populist government, when certain features associated with Africa were incorporated and the "Afro-Brazilian" was invented. We can point to the concrete cases of samba and carnival, but also to capoeira, cuisine, and even the variant of Portuguese spoken in Brazil. The second phase occurred from 1994 to 2002, during the government of Fernando Henrique Cardoso, who was the first president to acknowledge racism as a national problem and denounce it. However, it was during the Lula era from 2003 to 2010 that new conditions and actors emerged, and with them possibilities for identity politics. I will mention just a few here: television and commerce discovered the Negro (although not the Indian); the institutionalization of the ideas and icons of multiculturalism, including the implementation of Law 10369/2003, which made the teaching of "History and Cultures of Africa and Afro-American Populations" compulsory at all levels of

2 Daryle Williams, Culture Wars in Brazil: The First Vargas Regime, 1930-1945 (Durham/London: Duke University Press, 2001).

${ }^{3}$ Lilia Schwarcz, The Spectacle of the Races: Scientists, Institutions, and the Race Question in Brazil, 1870-1930 (New York: Farrar, Straus and Giroux, 1996).

4 Livio Sansone, Blackness Without Ethnicity. Creating Race in Brazil (New York: Palgrave, 2003), chapter 2. 
education; the policy of university quotas for poor and black students, and other measures inspired by affirmative action. As well as that, a focus on programmes of bilateral collaboration known as a Sul-Sul (SouthSouth) perspective in external politics inspired the celebration of Africa and aspects of the African origins of the Brazilian people. There was a slow but steady growth in African studies, especially of the continent's history and anthropology, in Brazilian universities, which for the first time recruited specialists in their fields - many of them young. Attention was given to collective land rights on ethno-racial bases, to maroons, riverines, as well as traditional indigenous populations, while at last a new cultural politics sprang up whose guiding principle can be expressed concisely as the inclusion and patrimonialization of both concrete and abstract - or tangible and intangible - culture. The Brazilian Ministry of Culture and the State Secretaries of Culture launched a series of projects using completely new terminology within the sphere: Creative Commons, a new museum policy, cultural sites, territories of identity, ethnic tourism, and so forth.

As a result, the term "diversity" has now become a fixture in the Portuguese language, as something positive which should be maintained, being seen nowadays as a bonus for the Brazilian nation. For the first time in the history of the country, old "problems" such as Africa, the Negro, and the Indian have become, albeit gradually and contradictorily, a bonus. To that we may add the development and popularization of the notion of abstract or intangible culture, with a growing list of artefacts - such as samba de roda, the carnival parade of the Sons of Gandhi in Salvador, the Brotherhood of the Good Death in Cachoeira (Bahia), and musical instruments and traditional rhythms that had previously always been defined as essentially regional. It is a list whose tendency is to grow at an exponential rate, above all when local governments begin to discover that their culture "has value," as in the case of the municipality of São Francisco do Conde, the richest of the State of Bahia because of the royalties deriving from the huge oil refinery in its territory, which, in 2006, proclaimed itself the "Capital of Culture."

The new questions of the social verticality of a historically unequal country, with the emergence of more sophisticated and more specific demands of citizenship, create new sensitivities in the fields of authorship and intellectual property, image rights, authenticity, reparation demands, willingness to become a subject and to speak for oneself. All that puts limits on the freedom with which, when seeking to legitimize themselves, the various elites can appeal to the people.

All such novelties, sometimes at odds with each other, make possible a new configuration not only of the constructive process of collective identities, but also of memory, as much of subaltern groups as of the State, which alters and broadens the range of symbols within which identities are recreated, as much sectional as national. As mentioned, the 
process goes hand in hand with the rediscovery and reinvention of Africa. ${ }^{5}$

Now let us consider in more detail how, within a context of complex and changing cultural politics where many actions can be developed for the first time, the task of creating a type of ethno-racial museum, or rather an ethnographic one, might be more complex than first thought, even if in a digital format as in our case.

\section{Preserving African and Afro-Brazilian Memory}

The Digital Museum of African and Afro-Brazilian Memory began as a digital version of an anthropological archive and was therefore initially called the Digital Archive of Afro-Bahian Studies. Then, as it developed, it incorporated historians, curators, and library scientists into its team and network. The term "African" was included in the name to reflect the establishment of a series of exchanges with African archives and museums operating within a context that enriches the project in two ways. First, they have a great deal of documentation and material stemming from the colonial and - unfortunately to a much lesser extent - post-colonial imagery of Africa and black people there. Second, they are eager to develop new approaches and technologies for preservation, to ensure accessibility of documents, and to create digital exhibits. As regards the latter, for example, some of the staff of the Historical Archives of Mozambique have received training in the critical use of digital technologies in Salvador and Rio de Janeiro, and it is hoped that in the near future something similar can be organized for the staff of INEP, the main research centre of Guinea Bissau. Those institutions receive various equipment from foreign donors, but the local staff are not trained in what to digitize, nor how to do it and why, for example because information might have some use in the future even if it seems to have little use now. Also, there is hope concerning the production of an open-source prototype of a digital museum that could be used by African researchers to make their own museum, if they wish, in partnership with our Museum. Such a digital museum could also be the engine for joint semi-presential training and even graduate courses - where the same language, Portuguese, rather than an end in itself, comes to represent a useful tool. Distance learning at graduate level, in association with our digital museum galleries - each of which produces documents, courses,

5 On this process of the patrimonialization of aspects of popular culture together with a new reinvention of Africa, see, among others, the two recent anthologies edited by the author: Livio Sansone (ed.), Memórias da África. Patrimônios, museus e políticas das identidades (Salvador: Edufba, 2012); Livio Sansone (ed.), A Políticas do Intangível. Museus e patrimônios em novas perspectivas (Salvador: Edufba, 2012). 
material, animation, and so on ${ }^{6}$ - is a new frontier that could be of special interest in regions such as much of Brazil and Africa.

It is worth noting that Brazil is one of the countries in the Americas with the closest connections to the African continent, where ancestral links emerge in our everyday life in an intense way, often leading us to think of them as authentic Brazilian manifestations, so much so that we forget their real origin. To that may be added the effort the current Brazilian government is making to become diplomatically closer to African countries, and of course commercial interests in pursuit of new markets for Brazilian goods, services, and technologies are a key factor. Yet all of that goes together with policies and practices that stimulate academic and scientific exchange with African institutions, as well as increase the number of grants to encourage the exchange of students and scholars - especially Lusophone - between African and Brazilian academic institutions for research and experience purposes. Until recently Brazil has traditionally been a country that received a good number of scholars from the North, but very few Brazilians ever gained experience of research abroad - certainly not in the Global South. Even though the situation is not free from self-interest, especially when it concerns large companies now investing in Africa, there is a fair degree of genuine curiosity and potential generosity towards Africa among many Brazilians.

The Digital Museum can be understood as a democratizing zone in which relations of otherness and constructions of identity are produced, that is, forms of recognition of local, regional and national emotional affiliations. By its very nature, it is also an easily accessible, dynamic, and interactive device that mirrors the daily life and culture of different communities, ethnic minorities, and marginalized groups that are recognized by their common values, traditions, and local affiliations, and their individual and collective memories.

The Museum is also a conceptual space that stimulates the use of the social memories of ethnic minorities and social movements, and of national memory in general. In that sense, the idea of constructing an archive and museum of living memories, transmitted on the Internet, demands a meaningful dialogue on matters related to both tangible and intangible ethnic heritage involving different users. Such a proposal will contribute to the integration of classical and popular culture, while also permitting a younger audience - the primary consumers of new technology - access to cultural benefits as a strategy to create new sensibilities and knowledge.

The preservation of the memory and intangible heritage of the AfroBrazilian population and the question of image rights represents a more

6 In July 2013 we plan to launch our first national digital exhibition, called "Brazilian Houses;" in 2014 we will have our second one: "Blacks and Football." 
than current issue. In Brazil, little has been done to preserve the memory of the conflicts and daily life of the Afro-Brazilian population; indeed, their museums, galleries, archives, and centres of documentation are few in number and in poor condition. The effort required to preserve such memory is still lacking within the large institutions that should perform that function, above all the National Library (BN) and the National Archive (AN), but also within the more specialized archives such as the Joaquim Nabuco Foundation (Fundaj) in Recife and the Edgard Leuenroth Archive at the State University of Campinas (Unicamp) in São Paulo state. I anticipate that our Digital Museum project will try to raise the awareness of those institutions too, in the sense of getting them to include among their priorities the "black issue," meaning race relations, racism, and Afro-Brazilian culture. They must review their collections, and change their indexing systems to include terms such as race or colour, racism, Negro, Afro-Brazilian, and Africa. Finally, priority must be given to those topics in their exhibitions and publications. ${ }^{7}$

Although it can be difficult and painful to recall the time of slavery, above all when it has left its long-lasting mark in contemporary inequalities such as racial discrimination, and especially when it still affects the majority of the population, it is now positively necessary to do so. ${ }^{8}$ The federal law of 2003 that demands the teaching of African and Afro-Brazilian cultures as a part of the social sciences cannot be effectively implemented without the preservation of collections of documents, visual images of all sorts, and audio-visual materials including interviews with black mães/pais-de-santowho are the priestesses and priests of Afro-Brazilian religions - activists, politicians, and intellectuals; or sound recordings of samba de roda groups, congadas, ternos de reis and so on. In other words, one way of giving visibility to the Afro-Brazilian population is to ask oneself what is the best form of nurturing their memory and their tangible and intangible cultural heritage. We must ask too what use to make of such memories, for there is a variety of possible uses, including academic, within the context of activism, documentary, or purely commercial.

Along with the need to preserve memories, sounds, and images, there are other developments in Brazilian society that must be confronted fully and openly. In the recent years of the consolidation of democracy in Brazil, the notion of citizenship has been expanding in the sense of incorporating the desire for greater control by the individual over public use of the image

7 The special issue of the National Archive's magazine, Acervo, published in 2010 and dedicated to the Negro is indicative of a positive change.

8 Livio Sansone, "Remembering Slavery from Nearby. Heritage Brazilian Style," in: Gert Oostindie (ed.), Facing Up to the Past: Perspectives on the Commemoration of Slavery from Africa, the Americas and Europe (London: Ian Randle/James Currey, 2000), 83-89. 
of the citizen, above all the black citizen. What then is the best way to understand and overcome the dilemma that seems to set the duty to preserve the collective memory of the Afro-Brazilian population's experience against a growing demand by them for the right to control how photographs, images, lyrics, and songs produced by blacks or associated with them are published and circulated?

Our Digital Museum project considers that tension and so works by a code of conduct that safeguards the individual's right to images while realizing the need to exhibit them, and to listen to recordings and read texts produced by blacks. We must satisfy the growing curiosity about African and Afro-Brazilian history and culture which exists throughout the extensive layers of the population, and we must reveal above all those who, until now, have not been properly represented but have been condemned to silence or invisibility. And how do we cope with the new tensions that result from the process by which certain cultural forms, finally "discovered" and, at times, defined as intangible heritage, pass suddenly from invisibility to hyper-visibility, such as happens when, for example, a hitherto very "local" samba de roda group is introduced to play in the media spotlight (samba de roda is a genre of samba recently registered on the list of intangible heritage maintained by the IPHAN)?

To patrimonialize Afro-Brazilian heritage also implies, in some form, defining what that culture is, from what elements it is composed. The need to determine the particular traits of a culture is in tension with the dynamic notion of culture that is today canonical in all the social sciences. In fact, we need to build a consensus around what we might call the common denominator of Afro-Brazilian culture. ${ }^{9}$

Other challenges are offered by the large size of the Afro-Brazilian population, which, far from being a minority, comprises more than half the total population of Brazil, and the huge variety of cultural expressions associated with the black population. There is also the importance of the "black question" in Brazilian history. The dilemma is that, far from being able to reflect such grandeur and complexity, our Digital Museum must necessarily make a selection of expressions, themes, and areas case-by-case and region-by-region but without thereby falling into the trap of reductionism.

New communication technologies have a profound impact on the construction of collective memory and its relationship with the process of identity. The assumption of an identity today is not a process or project carried out by the same methods as were used before the popularization of the Internet and the mobile telephone, and all their digital trappings. It is necessary to reflect more closely on the interface between

9 Livio Sansone, "Que Multi-Culturalismo para o Brasil," Ciência e Cultura (SBPC) 59 (2007), 24-29. 
technology and the way we remember, celebrate, choose, and organize our ideas as much in our own minds and thoughts as in relation to those of others.

Virtual or digital museums should not be seen as substitutes for physical ones; digital and physical visits - or tactile and digital experiences - should be seen as complementary rather than adversarial. However, I am acutely aware of the irony by which digital museums, as well as intangible heritage, seem in some way to be the "solution" to the historic lack of museums in the Global South, as it is the Global North that focuses more on tangible heritage and physical musealization. I do not believe digital technology to be the solution in itself, but, without any doubt, it provides a new context and offers new possibilities. It should not, however, become a sort of sacred cow, and it must always be understood within the logic of politics - digital politics. The digital medium is a means, not an end in itself; in fact, we could say it is rather like learning a foreign language - useful only if you have something to say in it.

More than an antidote, the Internet reflects inequalities - and it makes them clear for others to see and interpret. Information passed via digital media, in the quantity and organization - or disorganization - that it restores, as Baudrillard would say, is a dilemma of a new aphonia opposite the new plethora of information, in which knowing how to choose becomes a question of status - knowing how to choose defines one of the principal characteristics of the new intellectual elite. Facing these new challenges and possibilities may be similar to what Gramsci suggested in relation to activism: we need to be (techno) sceptical, but allowed to be moved by the optimism of (digital) action.

\section{A Museum without Owners}

The Digital Museum began in 1998 at the dawning of the International Advanced course in ethnic and racial studies called "Factory of Ideas" (www.fabricadeideias.ufba.br), at the Center for Afro-Asian Studies, Candido Mendes University, in Rio de Janeiro. Since 2002, the Factory of Ideas has been part of the Graduate Program in Ethnic and African Studies at the Center for Afro-Oriental Studies at the Federal University of Bahia (UFBA). The museum began with a collection of newspaper and magazine articles in the Brazilian press about a Negro movement, racism, and Africa. The pieces were initiated under the coordination of Carlos Hasenbalg, and received funding support first from the Mellon Foundation and later from the Sephis Programme for the rescue of archives in danger. Our Digital Museum project intends to take advantage of the international network of almost 450 researchers, developed thanks to the sixteen editions of the International Advanced course. Ideally, each of the researchers will be able to become a collaborator in our interactive museum project - providing the digital copy of documents as well as suggestions, criticism, and contacts. 
Our Digital Museum is, indeed, desperately keen to acquire a large network of reception antennas.

The Digital Museum has already received support from important national and international groups, including the Prince Claus Foundation, the National Council for Scientific and Technological Development $(\mathrm{CNPq})$, the Co-ordination for the Improvement of Higher Education Personnel (CAPES), Financier of Studies and Projects (FINEP), and the Research Support Foundations of the States of Bahia, Rio de Janeiro and Maranhão. We have established a series of institutional partnerships with the Brazilian Association of Anthropology, among other bodies. We are participants in the network of the Virtual Memory of the National Library Foundation (FBN) and are developing a partnership with the National Archive (AN), which means we shall soon be able to prioritize the question of the Negro, since the AN recently highlighted the subject of torture during a fascinating digital exhibition. Through the Dspace platform, the FBN will be our digital repository and, with continually updated resources, will hold high-definition digital copies (300 dpi) of all the documents our Digital Museum makes available. ${ }^{10}$ The documents in our Digital Museum can be used freely for educational and research purposes, it being sufficient to cite the original text and our Digital Museum. Anyone requiring high-definition copies, perhaps for publishing purposes, will be able to obtain them from the appropriate sector of the FBN.

Our collection is as much "inherited" from already extant archives as it has been created from scratch through new research and document acquisition. Inheritance of documents refers to the digital copy recuperation process, be it total or partial, from collections already present in the archives - copies that we can exhibit in themed galleries composed of documents from various archives. ${ }^{11}$

In order to describe what is involved in the creation of our collection, it is useful to refer to four policy concepts that guide our work: digital repatriation, digital donation, digital ethnography, and digital generosity.

Digital repatriation: We suggest to foreign archives that they continue to conserve original documents, but urge them to be altruistic with the digital copies, which we believe should be circulated freely without any significant

10 Initially, they will be in a lower resolution ( $64 \mathrm{dpi})$ to allow quicker navigation, or owing to copyright restrictions.

11 This is an idea developed at a meeting with the AN team in 2009, where the director, Jaime Antunes, proposed that our DM could also function as an archive of archives. 
cost of reproduction, thus permitting researchers to analyse documents without necessarily having to interrupt their work to travel abroad. ${ }^{12}$

Digital donation: We intend to inspire a policy and practice of making available documents that were previously difficult to access or entirely inaccessible. We mean to do that through our homepage, by means of a digital transfer tool already available there, and, indicating the National Library as a digital repository, through the Dspace platform. We do not wish to keep original documents nor items, but only to digitize them, archive them, and display them as museum pieces in our virtual galleries. The originals will be returned to their owners, after cleaning if necessary, using improved methods of storage according to the criteria of the most up-to-date archival science. We aspire eventually to be a museum without owners. In certain cases, especially when there is a risk that original documents might be lost or suffer damage, perhaps through poor earlier preservation or because they might be sold abroad or lost to private collections, then retention of such items can be mandated within an archive or public library as documents of public interest, both in order to avoid their being sent abroad - as often happened in the past - and to facilitate the sourcing of resources for proper conservation. The value of correct conservation processes cannot be over-estimated, above all in relation to the north-east of Brazil, where there is a grave shortage of public institutions, whether public archives, libraries, or museums. Furthermore, north-east Brazil seems to be a region where the public visit such facilities much less, as Myrian Santos has noted. ${ }^{13}$ That is why that region, with its large black population, is where we will focus our attention, although of course with no detriment to other regions, in our campaign to raise awareness of digital donation.

Digital ethnography: This method addresses the reception of documents and at the same time the awareness of specific communities, in the sense of adhering to the movement for digital donation. We will do this through

12 We already have copies of documents from leading researchers (see website), either repatriated or donated, with the support of the Smithsonian Institute in Washington DC, the Archive of Traditional Music at the University of Indiana at Bloomington, the Moorland-Spingarn Research Center at Howard University, the Schomburg Center for Research in Black Culture at the New York Public Library, the UNESCO Archives in Paris, and the AEL at UNICAMP, in the case of Donald Pierson's collection. Arrangements for getting digital copies from the Melville J. Herskovits Library of African Studies at Northwestern University are in progress at the moment of writing. We are slowly perusing/researching those collections of great interest to us in Brazil, in the BN, AN, Fundaj, and other smaller archives (such as the Geographical and Historical Institute of Bahia, the Jair Moura da Capoeira Archive, the private collections of researchers, activists, Candomblé houses, trade unions, and collectors). We completed the first national inventory at the seminar to launch our DM on 10-11 June 2010.

13 Myrian Sepúlveda dos Santos, "Museums Without a Past: The Brazilian Case,” International Journal of Cultural Studies 6-2 (2003), 180-201. 
research in the field by means of a mobile digital scanning station and, later, a sort of travelling museum, permanently under development and never seeming to be finished, searching out its audience and creating moments of drama, for example about memories of slavery in the Bahian Recôncavo.

Digital generosity: This point sets out from the premise that we are experiencing a new and growing anachronism in the process of creating the diffusion of knowledge: today, more books than ever, and texts in general, of an academic nature are being produced and edited and they can be more easily and quickly translated than before too. However, the use and interpretation of such information is not so easy to put into context; indeed, text and context go hand-in-hand less than ever before. Was it ever possible to trace the genesis of a text and complete an authentic archaeological investigation of its production process without being able to base our reflections on field notebooks, notes, writings, sketches, and the exchange of letters that the archaeology of knowledge thinks it is today? Hypertext is already penetrating our research practices, and the daily exchange of opinions between colleagues. Few bother to save their emails, which are always too often and frequently written according to what the philosopher and writer Hans Magnus Enzensberger, in referring to the late 1960's European community talk-radio stations, called "filthy discourse" grammatically imperfect and full with jargon, invented terms and dialect. ${ }^{14}$ On the other hand, in its exploration of new methodological frontiers the Internet could well become a great new way to share research experience. Learning to share both secondary and even primary data where possible, suggestions, tips, questions, answers, annotations - all this is possible through the Internet. In some cases, perhaps as a way of becoming the subject instead of just the object of research, our own sources will be able to have a presence on the Digital Museum's homepage, at least the key ones will, those who care most about maintaining contact with others who are researching their subjects' individual and collective reality. In that sense, a prototype portal might be created where researchers could exchange their experiences within a sort of chat room inside our Digital Museum - collective curatorship that benefits from the opportunities created by the internet for new forms of crowdsharing and crowdsourcing.

With respect to copyright, we believe in the philosophy that guides the Creative Commons movement: citation is necessary, but payment is not. As part of our Digital Museum's work, questions of copyright arise with the use of software in accordance with image rights, the safeguarding of privacy, and the digital reproduction of a document and its subsequent availability on the Internet.

14 Hans Magnus Enzensberger, The Consciousness Industry: On Literature, Politics and the Media (New York: Seabury Press, 1974). 


\section{Documents in the Digital Museum}

We began the Museum with a series of collections featured in the United States and France which, until then, had not been available to a wide Brazilian audience because they were either not digitized or were unavailable online. The virtual "repatriation" of those records, in cooperation with foreign institutions that provide digitization and availability through the Internet, has been the first stage of our programme, although it is still incomplete because many pieces remain in the collections of foreign researchers which are more difficult to access.

It is important to specify what we mean by a document in the context of our Digital Museum. It is, of course, well known that the term "document" is polysemic and that every document is in fact a monument. As far as digitization is concerned, which documents we select are the results of policy, decisions, and processes of monumentalization and patrimonialization. Specifically, the documents to which we give priority are taken from a wide range that obviously includes written sources, but is not limited to the written record in the narrower sense. We are interested in printed material such as newspaper articles, minutes of meetings, unpublished original texts, private documents, letters, poetry, traditional recipes both culinary and medicinal, photographs, iconography, sound recordings and music scores, testimonials both pre-recorded or produced ad hoc by our own team, prayers, tunes, reproductions of cultural objects or artefacts, and film footage and recordings of cultural or political events. Above all we consider:

1. Documents, whether already in archives or private collections. That is as much the files "about" the Afro-Brazilian population as, to a lesser extent, the records produced by Afro-Brazilian anthropologists, intellectuals, artists, activists, religious leaders, and so on. We can be a Museum of Museums and an Archive of Archives: for example, we can hold temporary exhibits alongside pieces from different archives or museums - pieces that could then be exchanged through a digital lending policy.

2. Documents secured or produced by researchers which we then circulate online, authorizing either their partial or full publication during or after the completion of research.

3. Documents created from scratch, above all their appropriation when there are no previous records. These may be testimonies, photographs, music recordings, and so on. It might refer also to previously produced documents recording or registering as a determined group or community receives our project and researchers as people receive, comment, and sometimes dramatize images and documents about their own reality that we present for them. This last form of acquiring documents and registering the Afro-Brazilian 
memory we should like to call "the barnstorming museum" — the type of museum as mobile, as it is eternally unfinished, seeking and in fact creating its own audience.

\section{How We Choose the Records}

For the recovery of the Afro-Brazilian memory, well-known figures in the social, political, and intellectual life of Brazil interest us as much as do the anonymous and unknown ones - for example, mães/pais-de-santo, or the first classes of students admitted to a public university as a result of the new quota system.

The site, with dynamic ideographic screens, will be continually updated as new material is produced so that subjects and researchers can communicate about documents already online and add others according to the principles of generosity and digital donation. In that sense, our project provides constant research and the updating of software or more adaptable platforms to facilitate content management and the creation of digital repositories.

In the first instance at least we consider documents and materials produced by people who identify themselves as black or Afro-Brazilian, because that is where the main need resides, and alongside them we look for material on Afro-Brazilian religious leaders, black activists, trade unionists, classical and popular musicians, capoeira schools and teachers, maroon community leaders, NGOs concerning the Afro-Brazilian population, the Catholic Church (especially the Pastoral Care of the Negro) and some Pentecostal churches, and the personal archives of components of the black elite. ${ }^{15}$ Important too will be records still unpublished or, if already published, to which access is difficult, records produced "about" or "for" blacks or Afro-Brazilians, records of race relations, and more general material about a variety of figures either from the professional or intellectual worlds who have observed the reality of circumstances throughout the history of Brazil. Of interest too are travellers, missionaries, diplomats, faith workers, essayists, journalists, anthropologists, and other social scientists.

\section{A Network of Collaborators}

We are working with regional teams that enjoy full autonomy, based in four of the Brazilian states, namely Maranhão, Pernambuco, Rio de Janeiro, and

15 We are relying here on the research of Angela Figueiredo and Ivo de Santana, both associated with our research group. 
Bahia. ${ }^{16}$ Our Digital Museum is a research instrument with the characteristics of a public service and works with a headquarters team of researchers and technicians, and then a wider network of collaborators. They include active researchers in the academic field, and with them collectors, self-taught researchers, activists, and curators. However, our Digital Museum should be more than a digital archive. We hope visits will be made on various levels, and there will be interaction between users and the Museum, including the creation of points of memory and document reception in the public spaces. We want to operate through the Internet, with the support of our advisory board, which unites researchers, curators, intellectuals, artists, and activists from various countries and meets periodically via videoconference, as well as with the support of an association of friends of the Digital Museum, who can be relied upon and will inspire a virtual discussion of our Museum, on our homepage.

Collaboration can take various forms. Digital material can be donated, there is suggestion and criticism, or someone can take on the job of constructing and curating a virtual gallery consisting of a set of documents focusing on a specific topic made available to the Museum from various sources. Our policy is to ask individual researchers to be responsible for the construction of "their" gallery.

\section{Challenges}

Our first phase of activity has brought with it a series of enormous challenges. We had to make quick decisions about dealing with things such as authenticity (what is an authentic document?); originality (which documents to choose within frequently quite large groups?); property (which property to recognize or reject? And to what extent?); exclusivity (that phenomenon finding expression among historians as the category "my documents" and among anthropologists as "my informants"); copyright, image rights, and privacy (can everything be made public? What is public or private; why, for what purpose; and whom to ask for authorization?); the status of the researcher (what to do with the self-taught ones); whether and how to incorporate the archives of social movements, associations, and NGOs; what type of exchange to weave with other virtual or digital museums; what

16 Thus far, our DM has teams from the Federal University of Maranhão (UFMA), the Federal University of Pernambuco (UFPE), the State University of Rio de Janeiro (UERJ), and the Federal University of Bahia (UFBA). Each team has its own homepage, but all are synchronized with the project's homepage and they use the same software, differing primarily only in their graphic appearance and the way in which they musealize documents or favour the recovery of certain endangered files, or the creation of new documents, or even the organization of galleries on the basis of documents already present in paper archives. 
relationship to maintain with projects of archive digitization, for example in Africa - it must be for the exchange of technology or of documents on subjects of transatlantic importance, such as miscegenation, elites or colonists of colour, and racist iconography.

Our Digital Museum will also be a museum of race relations and hierarchies such as that of racism. The testimony of both blacks and whites will be as important as records found in documents, processes, or newspapers. To place racism into the context of a museum, even a digital one, naturally demands that we reflect on what it means to contemplate pain and evil. Reflections on the Holocaust and slavery, and museums of apartheid, will therefore be a source of inspiration.

Finally, our project is challenged by having to develop new forms of virtual musealization, creating galleries that take advantage of documents and pieces of our own and other digital archives, to make them dynamic and somehow spectacular. In short, how does one make a contemporary virtual museum thrilling to a wide variety of audiences?

Our Digital Museum, through it all, is as much a public service as it is a tool for research and to stimulate reflection upon the social sciences and their applicability, particularly to the questions raised by the development of the new Brazilian-style multiculturalism, and the relationship between new communication technologies and the use of human memory. We want to make a concrete contribution to the creation of a new geopolitics of knowledge. To create museums and archives from the South and from a Sul-Sul (South-South) perspective, even in the case of digital or virtual experiences, will contribute to reversing traditional ways of associating place with knowledge and with the preservation of knowledge. Therefore, we believe it is sensible to start thinking about a new, more critical and less "natural" conservation policy - one that will question the current relations of power surrounding the process.

\section{References}

Enzensberger, Hans Magnus, The Consciousness Industry: On Literature, Politics and the Media (New York: Seabury Press, 1974).

Sansone, Livio, "Remembering Slavery from Nearby. Heritage Brazilian Style," in: Gert Oostindie (ed.), Facing Up to the Past: Perspectives on the Commemoration of Slavery from Africa, the Americas and Europe (London: Ian Randle/James Currey, 2000), 83-89.

— Blackness Without Ethnicity. Creating Race in Brazil (New York: Palgrave, 2003).

—_, "Que Multi-Culturalismo para o Brasil," Ciência e Cultura (SBPC) 59 (2007), 24-29.

Sansone, Livio (ed.), Memórias da África. Patrimônios, museus e políticas das identidades (Salvador: Edufba, 2012).

, A Políticas do Intangível. Museus e patrimônios em novas perspectivas (Salvador: Edufba, 2012). 
Santos, Myrian Sepúlveda dos, "Museums Without a Past: The Brazilian Case," International Journal of Cultural Studies 6-2 (2003), 180-201.

Schwarcz, Lilia, The Spectacle of the Races: Scientists, Institutions, and the Race Question in Brazil, 1870-1930 (New York: Farrar, Straus and Giroux, 1996).

Williams, Daryle, Culture Wars in Brazil: The First Vargas Regime, 1930-1945 (Durham/ London: Duke University Press, 2001). 